Eur. J. Clin. Chem. Clin. Biochem.

Vol. 30, 1992, pp. 467-471

(C) 1992 Walter de Gruyter \& Co. Berlin · New York

\title{
Coagulation and Fibrinolysis Markers in Seminal Plasma of Patients under Evaluation for Involuntary Childlessness
}

\author{
By J.W. J. van Wersch ${ }^{1}, J . C$. De Vries-Hanje ${ }^{2}$ and J. M. H. Ubachs ${ }^{2}$ \\ ${ }^{1}$ Department of Haematology \\ ${ }^{2}$ Department of Gynaecology \\ De Wever Hospital, Heerlen, The Netherlands
}

(Received July 30, 1991/March 9, 1992)

Summary: Semen specimens from four groups of patients were evaluated for coagulation and fibrinolysis factors:
a group of patients with infertile semen and involuntary childlessness $(n=35)$,
a group with fertile semen and involuntary childlessness $(n=39)$,
a group with fertile semen and proven fertility before vasectomy $(n=34)$ and
a group with infertile semen after vasectomy $(n=147)$.

The third patient group with proven fertility before vasectomy was considered as a control group. Only small amounts of fibrinogen, factor VIII:c, plasminogen, antithrombin III, fibrin monomers and plasminogen activator inhibitor-1 were detected in seminal plasma. The thrombin-antithrombin III, D-dimer and tissue plasminogen activator regular concentrations were measured and the D-dimer/thrombin-antithrombin III ratios calculated. The reference ranges were assessed and the quantities were compared in the different patient groups. Significant differences were demonstrated between the prevasectomy group (= control group) and both the postvasectomy and the infertility groups with respect to D-dimer and D-dimer/thrombin-antithrombin III ratio. We conclude that both coagulation and fibrinolysis play a part in coagulum formation and liquefaction of seminal plasma. The balance between coagulation and fibrinolysis (expressed as D-dimer/ thrombin-antithrombin III ratio) was significantly different between the control group and the three patient groups. The coagulation/fibrinolysis balance was impaired in the semen from post vasectomy patients and from those with involuntary childlessness and the D-dimer/thrombin-antithrombin III -ratios in both these patient groups were very similar.

\section{Introduction}

Immediately after ejaculation, semen is coagulated and liquefaction takes 5 to 20 minutes (1). The clotting process is induced by the enzyme vasiculase originating from the prostate gland. The coagulum consists of a fibrin-like material, which is considered to be composed of sialo-glycoprotein-metal complexes (2) and of glycerylphosphorylcholine (3). The high molecular weight seminal vesicle protein is degraded by proteases of the prostatic fluid when the clot liquefies
$(4,5)$. It has been suggested that the degree of coagulation of ejaculated semen may be correlated with epididymal function (3) and that subfertility may be associated with poor coagulation caused by a lower osmolality and buffering capacity and a higher $\mathrm{pH}$ than samples showing good coagulation (6). The aim of the study was to assess if the fibrin-like coagulum contained (or had contained) fibrin by measuring coagulation activation and fibrinolysis products in the seminal plasma after liquefaction, and to establish 
reference ranges in normal seminal plasmas. Finally the measured quantities were compared in involuntarily childless and normal males. The relevant part of the coagulation and fibrinolysis cascade is given in figure 1.

\section{Materials and Methods}

Methods

Fibrinogen was measured with a clotting assay (Merz and Dade) according to the method of Clauss, by means of a Schnitger and Gross coagulometer. Factor VIII:c was determined in a one stage clotting assay with the aid of a F VIII deficient plasma of Behring (Marburg, Germany). Antithrombin III was assessed with a chromogenic substrate method of the Behring Corporation (Germany). The chromogenic Coa set FM test of Kabi Vitrum Diagnostica (Mölndal, Sweden) was used for the fibrin monomer determinations. The thrombinantithrombin III was determined using an ELISA test kit from Behring (Behring Marburg, Germany). The fibrin degradation products were measured by means of the D-dimer test (Boehringer Mannheim, Mannheim, Germany). The D-dimer test is a specific ELISA test for the determination of degradation products of cross-linked fibrin only and not of fibrinogen. Plasminogen activator inhibitor-1 and tissue plasminogen activator activity were quantitated by measuring the enzymatic activity of the plasmin generated in the test procedure in the presence of fibrinogen fragments against the synthetic substrate S-2251 (Kabi Vitrum Diagnostica).

\section{Precision of the methods}

For thrombin-antithrombin III the intra-assay and inter-assay coefficient of variation were $5.1 \%$ and $7.4 \%$ respectively. The D-dimer analysis showed a intra-assay coefficient of variation of $7.1 \%$ and an inter-assay coefficient of variation of $10.0 \%$. The coefficients of variation obtained for the tissue plasminogen activator activity assay were $6.2 \%$ for the intra-assay variation and $10.1 \%$ for the inter-assay variation.

\section{Samples}

The semen was obtained at home after masturbation and was collected in graduated tubes. The material had to be presented in the laboratory whithin one hour of production. The semen was centrifuged after liquefaction ( $2000 \mathrm{~g}$ at room temperature, $10 \mathrm{~min}$ ) and the seminal plasma collected. The supernatant was deep frozen at $-70^{\circ} \mathrm{C}$ until the next batch of measurements.

\section{Patients}

Quantities associated with coagulation and fibrinolysis were investigated in the seminal plasma of 255 patients. The patients under evaluation for infertility were subdivided into two groups: group I $(n=35)$ consisted of men with infertile semen according to the sperm concentration and motility and group II $(n=39)$ of men with fertile semen according to the sperm concentration and motility, but without proven fertility. It is considered to be normal if the sperm concentration is $>20$ $\times 10^{9} / 1$ and the progressive motility is $>30 \%$ (7). The seminal plasma for male individuals with proven fertility, who came to the urology clinic for vasectomy (group III, $n=34$ ), was used as a positive control group; the seminal plasma of a group of vasectomized patients (group IV, $\mathrm{n}=147$ ) was used as a negative control group. All the patients underwent urological examination for the exclusion of anatomical, infectious and endocrinological abnormalities. In the group of males attending the clinic for assessment because of a marriage with delayed fertility, female infertility factors were excluded.

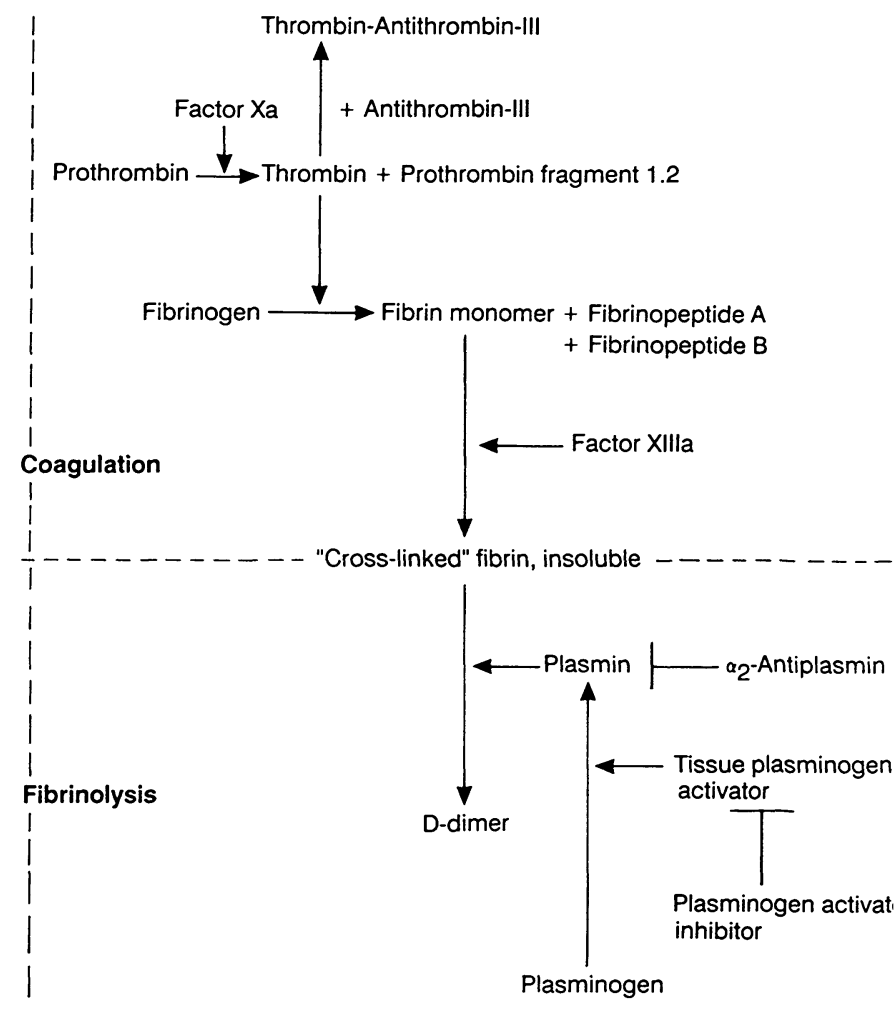

Fig. 1. Relevant part of the coagulation and fibrinolysis cascade

\section{Statistical analysis}

The Mann-Whitney-Wilcoxon test was employed for the comparison of the patient groups with each other and of the patient groups with the reference group.

\section{Results}

As can be seen in table 1, measurable quantities of fibrinogen, plasminogen, plasminogen activator inhibitor-1, factor VIII:c and fibrin monomers could not be detected, and the antithrombin III level was low $(0.2-0.6 \%)$.

In table 2 the reference ranges for the relevant quantities in blood plasma are given.

Table 3 summarizes the data on the volume, spermatozoa count, thrombin-antithrombin-III, D-dimer, D-dimer/thrombin-antithrombin III ratio, tissue plasminogen activator activity and the percentage of propulsively moving spermatozoa for the prevasectomy and postvasectomy groups as well as for the infertility groups. The mean values of the patient groups I and II were compared with the control group III and the postvasectomy group. Significant differences were found between group I and control group III for the D-dimer/thrombin-antithrombin III ratio $(\mathrm{p}=0.004)$ and the $\mathrm{D}$-dimer level $(\mathrm{p}=0.033)$. Significant differences between group II and III were found for Ddimer $(p=0.007)$ and the D-dimer/thrombin-antith- 
Tab. 1. Determinations of factors present in low concentrations in seminal plasma.

\begin{tabular}{llcc}
\hline Quantities & Values in seminal plasma & Units & $\begin{array}{c}\text { Reference values } \\
\text { in blood plasma }\end{array}$ \\
\hline Fibrinogen & $<0.1$ & $\mathrm{~g} / 1$ & $1.7-4.0 \mathrm{~g} / 1$ \\
Antithrombin III & $0.2-0.6 \%$ & $(600-1800 \mu \mathrm{g} / \mathrm{l})$ & $80-120 \%$ \\
Plasminogen & $<1$ & $\%$ & $85-130 \%$ \\
F-VIII:c & $<1$ & $\%$ & $61-176 \%$ \\
Plasminogen activator inhibitor-1 & $<1$ & $\mathrm{n} \% \mathrm{O}-4.6 \times 10^{3} \mathrm{AU} / 1$ \\
Fibrin monomer & $<1$ & $8.4-13.2 \mathrm{nmol} / 1$ \\
\hline
\end{tabular}

Tab. 2. Reference ranges of the relevant quantities in blood plasma of healthy volunteers.

\begin{tabular}{lll}
\hline & $\begin{array}{l}\text { Reference ranges } \\
\text { in blood plasma }\end{array}$ \\
\hline Thrombin-antithrombin III & $(\mu \mathrm{g} / \mathrm{l})$ & $\left.1-4.2^{1}\right)$ \\
D-dimer & $(\mu \mathrm{g} / \mathrm{l})$ & $\left.0-450^{2}\right)$ \\
D-dimer/TAT-III-ratio & $\left.0-184^{2}\right)$ \\
Tissue plasminogen activator activity & $\left(10^{3} \mathrm{IU} / \mathrm{l}\right)$ & $\left.0.6-2.6^{1}\right)$ \\
\hline
\end{tabular}

1) mean $\pm 2 \mathrm{SD}$

2) $0^{\text {th }}$ to $95^{\text {th }}$ percentile

rombin III ratio $(p=0.02)$. There were no significant differences between the vasectomized patients and group III, nor could any significant difference be found between groups I and IV or II and IV. Significant differences were found for the D-dimer levels and D-dimer/thrombin-antithrombin III ratios between the postvasectomy group IV and the prevasectomy patient group III (p-values 0.026 and 0.0008 , respectively).

\section{Discussion}

The presence of the coagulation and fibrinolysis markers thrombin-antithrombin III and D-dimer, together with the extremely high tissue plasminogen activator levels (in comparison with the blood plasma concentrations), is an indication that they have a function in semen and that the seminal coagulum is at least partly composed of fibrin. It seems that the low antithrombin III concentration $(600-1800 \mu \mathrm{g} / \mathrm{l})$ is high enough for the thrombin-antithrombin III complex formation in the concentrations measured in this study. We could not measure directly the presence of prothrombin but in the meantime we found considerable amounts of prothrombin fragment 1.2 in the seminal plasma (still unpublished data). This is indirect evidence for the presence of the prothrombin needed for fibrin production. Fibrin once formed is known to provoke fibrinolysis by stimulating tissue

Tab. 3. Summary of the results in the different groups. The significance levels were:

1) I vs III $p=0.033,{ }^{2}$ ) II vs III $p=0.007,{ }^{3}$ ) IV vs III $p=0.026,{ }^{4}$ ) I vs III $p=0.004,{ }^{5}$ ) II vs III $p=0.02$, ${ }^{6}$ ) IV vs III $\mathrm{p}=0.0008$.

\begin{tabular}{|c|c|c|c|c|}
\hline Groups & $\begin{array}{l}\text { Group I } \\
(\mathrm{n}=35)\end{array}$ & $\begin{array}{l}\text { Group II } \\
(\mathrm{n}=39)\end{array}$ & $\begin{array}{l}\text { Group III } \\
(\mathrm{n}=34)\end{array}$ & $\begin{array}{l}\text { Group IV } \\
(\mathrm{n}=147)\end{array}$ \\
\hline Quantities & $\begin{array}{l}\overline{\mathrm{x}} \\
(\mathrm{SD})\end{array}$ & $\begin{array}{l}\overline{\mathrm{x}} \\
(\mathrm{SD})\end{array}$ & $\begin{array}{l}\overline{\mathrm{x}} \\
(\mathrm{SD})\end{array}$ & $\begin{array}{l}\overline{\mathrm{x}} \\
(\mathrm{SD})\end{array}$ \\
\hline Volume (ml) & $\begin{array}{r}4.1 \\
(2.4)\end{array}$ & $\begin{array}{l}3.9 \\
(2.3)\end{array}$ & $\begin{array}{l}3.8 \\
(2.0)\end{array}$ & $\begin{array}{c}3.6 \\
(1.8)\end{array}$ \\
\hline Spermatozoa count $\left(10^{9} / 1\right)$ & $\begin{array}{l}15.6 \\
(25.3)\end{array}$ & $\begin{array}{l}57.9 \\
(61.0)\end{array}$ & $\begin{array}{l}63.3 \\
(45.8)\end{array}$ & $<1$ \\
\hline $\begin{array}{l}\text { Percentage of propulsively moving } \\
\text { spermatozoa }(\%)\end{array}$ & $\begin{array}{l}4.5 \\
(2.8)\end{array}$ & $\begin{array}{c}30.2 \\
(27.5)\end{array}$ & $>60$ & 0 \\
\hline Thrombin-antithrombin III $(\mu \mathrm{g} / \mathrm{l})$ & $\begin{array}{l}7.9 \\
(9.5)\end{array}$ & $\begin{array}{l}5.0 \\
(6.7)\end{array}$ & $\begin{array}{c}7.5 \\
(10.5)\end{array}$ & $\begin{array}{l}12.5 \\
(25.4)\end{array}$ \\
\hline D-dimer $(\mu \mathrm{g} / \mathrm{l})$ & $\begin{array}{c}\left.131^{1}\right) \\
(131)\end{array}$ & $\begin{array}{l}\left.120^{2}\right) \\
(207)\end{array}$ & $\begin{array}{l}213 \\
(175)\end{array}$ & $\begin{array}{l}\left.177^{3}\right) \\
(209)\end{array}$ \\
\hline $\begin{array}{l}\text { D-dimer/thrombin- } \\
\text { antithrombin III ratio }\end{array}$ & $\begin{array}{l}\left.27.0^{4}\right) \\
(34.1)\end{array}$ & $\begin{array}{l}\left.25.1^{5}\right) \\
(16.6)\end{array}$ & $\begin{array}{c}63.4 \\
(79.0)\end{array}$ & $\begin{array}{l}\left.34.7^{6}\right) \\
(49.7)\end{array}$ \\
\hline $\begin{array}{l}\text { Tissue plasminogen activator } \\
\text { activity }\left(10^{3} \mathrm{IU} / \mathrm{l}\right)\end{array}$ & $\begin{array}{c}366 \\
(239)\end{array}$ & $\begin{array}{l}323 \\
(282)\end{array}$ & $\begin{array}{l}296 \\
(247)\end{array}$ & $\begin{array}{c}244 \\
(172)\end{array}$ \\
\hline & $\begin{array}{l}\text { Infertile } \\
\text { semen } \\
\text { Involunta }\end{array}$ & $\begin{array}{l}\text { Fertile } \\
\text { semen } \\
\text { sness }\end{array}$ & $\begin{array}{l}\text { Proven fertile } \\
\text { semen, } \\
\text { prevasectomy }\end{array}$ & $\begin{array}{l}\text { Infertile } \\
\text { semen, after } \\
\text { vasectomy }\end{array}$ \\
\hline
\end{tabular}


plasminogen activator activity, which actually has been shown to be present in very high concentrations (9). The final result is then the formation of D-dimers.

The presence of plasminogen activator was demonstrated long ago by Suominen \& Niemi (8), but no plasmin-like proteinase activity was found. Very recently the presence of high tissue plasminogen activator antigen has been reported again by Maier et al. (10) both in spermatozoa and in seminal plasma. Little is known about the role of tissue plasminogen activator activity. But it might prevent the occlusion of tubular structures in the urogenital tract.

The D-dimer fragments as degradation products can only originate from previously formed cross-linked fibrin. Evidence for cross-linking activity has been found with the demonstration of transglutaminase secretion through the anterior prostate in guinea pigs (11) and rats (12). Transglutaminase or factor XIII activity, however, has not so far been detected in human semen $(5,13)$, although our results suggest such an activity. The initiation of coagulation activation might be partly explained by the presence of prostate-specific antigen, which is believed to be a kallikrein-like serine protease in prostatic fluid, which cleaves the predominant seminal vesical protein (14). It is well known that kallikrein is one of the activators of the intrinsic pathway of the clotting cascade.

Moreover Minhas et al. (15) have reported the presence of platelet-activating factor-like activity in human spermatozoa. Platelet-activating factor is a potent phospholipid with a wide spectrum of biological activities (16) which might induce activation of coagulation. Moreover Sugkraroek et al. (17) discussed the role of different levels of cholesterol and phospholipids in sperm from fertile and interfertile men. The presence of coagulation factors in seminal plasma need no longer be considered a strange phenomenon since Laurell et al. (18) recently reported the presence of very high concentrations $(220 \mathrm{mg} / \mathrm{l})$ of protein C inhibitor with a relative molecular mass of $M_{\mathrm{r}}=57000$ in seminal plasma. These concentrations are very high as compared with $5.3 \mathrm{mg} / \mathrm{l}$ in blood plasma. They demonstrated the local production of protein $C$ inhibitor in the male sex glands and the secretory origin in the seminal vesicles. Significantly lower values for D-dimer and D-dimer/thrombin-antithrombin III ratios were found in all groups of patients with infertility or after vasectomy in comparison with the control group. The D-dimer/thrombin-antithrombin III ratio can be seen as an indicator of the balance between fibrinolysis and coagulation. The decreased D-dimer/thrombin-antithrombin III ratio in both infertile and vasectomized patients suggests a disturbance of that balance, caused either by a shift towards coagulation activation, or to a reduction of fibrinolysis, or to both, and it is independent of the number of spermatozoa previously present. The D-dimer/thrombin-antithrombin III ratio is reduced in the infertile group as well as in the postvasectomy group, in whom no spermatozoa are present.

Groups I and IV show rather high thrombin-antithrombin III values with moderate D-dimer values, possibly indicating a retardation of the liquefaction of the coagulum, which might reduce the motility of the spermatozoa. This confirms a suggestion of Mandal et al. $(3,19)$ that there is a possible relationship between the coagulum liquefication properties of human ejaculates and the semen quality and that there is an association between subfertility and/or coagulum formation after ejaculation.

Furthermore, the similarity between the D-dimer/ thrombin-antithrombin III ratios in involuntary childless patients and in the postvasectomy patients is remarkable. The present results are an encouragement for further studies in this field, and they draw attention to coagulation and fibrinolysis markers in the evaluation of patients with fertility problems.

\section{References}

1. Mandal, A. \& Bhattacharyya, A. K. (1986) Grouping the ejaculates according to the degree of coagulation and the relationship to the levels of choline and cholinesterase. Int. J. Androl. 9, 407-415.

2. Polak, B. \& Daunter, B. (1989) Seminal plasma biochemistry. IV: enzymes involved in the liquefaction of human seminal plasma. Int. J. Androl. 12, 187-194.

3. Mandal, A., Batabyal, S. K. \& Bhattacharyya, A. K. (1989) Glycerylphosphorylcholine levels in the coagulational groups of human ejaculates. Indian J. Med. Res. 40, 186190.

4. Lilja, H. \& Laurell, C. B. (1984) Liquefaction of coagulated human semen. Scand. J. Clin. Lab. Invest. 44, 447-452.

5. Lilja, H. \& Laurell, C. B. (1985) The predominant protein in human seminal coagulate. Scand. J. Clin. Lab. Invest. $45,635-641$.

6. Mandal, A. \& Bhattacharyya, A. K. (1988) Differences in osmolality, $\mathrm{pH}$, buffering capacity, superoxide dismutase and maintenance of sperm motility in human ejaculates according to the degree of coagulation. Int. J. Androl. 11, $45-51$.

7. Kruger, T. F., Swanson, R. J., Acosta, A. A., Matta, J. F., Simmons, K. F. \& Oehninger, S. (1988) Predictive value of abnormal sperm morphology in in vitro fertilization. Fertility and Sterility $49,112-117$. 
8. Suominen, J. \& Niemi, N. (1970) Proteolytic enzymes in human seminal fluid. Scand. J. Clin. Lab. Invest. 25, suppl. 113, 52 (abstract).

9. Christ, G. \& Binder, B. R. (1989) Components of the fibrinolytic system in spermatozoa and seminal plasma of fertile and infertile men. Thromb. Haemostas. 62, 396 (abstract).

10. Maier, U., Kirchheimer, J. C., Hienert, G., Christ, G. \& Binder, B. R. (1991) Fibrinolytic parameters in spermatozoas and seminal plasma. J. Urol. 146, 906-908.

11. Williams-Ashman, H. G., Notides, A. C., Pabalan, S. S. \& Lorand, L. (1972) Transaminase reactions involved in the enzymic coagulation of semen: isolation of gamma-glutamyl- $\varepsilon$-lysine dipeptide from clotted secretion protein of guinea pig seminal vesicle. Proc. Natl. Acad. Sci. USA 69, $2322-2325$

12. Williams-Ashman, H. G., Wilson, J., Beil, R. E. \& Lorand, L. (1977) Transglutaminase reactions associated with the rat semen clotting system: modulation by macromolecular polyanions. Biochem. Biophys. Res. Commun. 79, 11921198.

13. Tauber, P. F., Zaneveld, L. J. D., Propping, D. \& Schumacher, G. F. B. (1976) Components of human split ejaculates. II. Enzymes and proteinase inhibitors. J. Reprod. Fertil. 46, 165-171.
14. Lilja, H. (1985) A kallikrein-like protease in prostatic fluid cleaves the predominant seminal vesicle protein. J. Clin. Invest. 76, 1899-1903.

15. Minhas, B. S., Kumar, R., Ricker, D. D., Robertson, J. L. \& Dodson, M. G. (1991) The presence of platelet-activating factor-like activity in human spermatozoa. Fertility and Sterility $55,372-376$

16. Kumar, R. \& Hanahan, D. J. (1987) Diversity of the biochemical and biological behavior of platelet activating factor. In: Platelet Activating Factor (Snyder, F., ed.) New York, Plenum Press, p. 239

17. Sugkraroek, P., Kates, M., Leader, A. \& Tamphaichitr, N. (1991) Levels of cholesterol and phospholipids in freshly ejaculated sperm and Percoll-gradient-pelletted sperm from fertile and unexplained infertile men. Fertility and Sterility $55,820-827$.

18. Laurell, M., Christensson, A., Abrahamsson, P-A., Stenflo, J. \& Lilja, H. (1991) Protein C inhibitor is present at micromolar concentrations in seminal plasma. Thromb. Haemost. 65, 854 (abstract).

19. Mandal, A. \& Bhattacharyya, A. K. (1987) Relationship between the coagulation-liquefaction property of human ejaculates and their volume, sperm count and motility. Clin. Reprod. Fert. 5, 367-371.

Dr. J. W. J. van Wersch

Haematological Laboratory

De Wever Hospital

P. O. Box 4446

NL-6401 CX Heerlen 
